\title{
Phenotypic and Molecular Characterization of Plasmid- Mediated Virulence and Antimicrobial Resistance Traits among Multidrug Resistant Enterococcus Spp. in Egypt
}

\author{
Mahmoud M. Tawfick ${ }^{1,2}$ (D) Nagwan G. El Menofy ${ }^{3 *}$ (D), Maha E. Omran³, \\ Omnia A. Alsharony and Maha A. Abo-Shady ${ }^{3}$ \\ ${ }^{1}$ Microbiology and Immunology Department, Faculty of Pharmacy (Boys), Al-Azhar University, Cairo 11884, \\ Egypt. ${ }^{2}$ Microbiology and Immunology Department, Faculty of Pharmacy, Heliopolis University, Cairo, Egypt. \\ ${ }^{3}$ Microbiology and Immunology Department, Faculty of Pharmacy (Girls), Al-Azhar University, Cairo,11884, \\ Egypt. ${ }^{4}$ Helwan General Hospital, Helwan, Cairo, Egypt.
}

\begin{abstract}
Enterococcus spp. are remarkable multidrug resistant (MDR) bacteria that are causing serious healthcare-associated infections. The current study investigated the frequency of Enterococcus spp., antimicrobial susceptibility, biofilm formation and the presence of some plasmid-mediated virulence characters and antimicrobial resistance determinants in enterococcal isolates from Egyptian hospitals in Cairo. Enterococcus bacterial isolates were recovered from different clinical specimens and identified using biochemical testing and KB005A HiStrep ${ }^{\text {TM }}$ identification kit. Kirby-Bauer disc diffusion method and/or broth microdilution method were used to determine the antimicrobial susceptibility patterns. Phenotypic assays were performed to study biofilm formation and cytolysin and gelatinase production. PCR assays targeting the plasmid-carried genes $\operatorname{aac}\left(6^{\prime}\right)$-aph (2'), aph(3)-IIIa, vanA, agg and cylA were performed. In this study, 50 isolates of diverse Enterococcus spp. were identified with E. faecium was the most frequently isolated one. High resistance profiles were determined against tested antimicrobials and all isolates were MDR. Moderate biofilm formation was detected in $20 \%$ of isolates, $18 \%$ showed complete blood hemolysis and $12 \%$ produced gelatinase. All isolates carried the tested aminoglycosides resistance genes, while vanA was found only in 4 isolates (8\%). The virulence genes agg and cylA were detected in $4 \%$ and $32 \%$ of isolates, respectively. In conclusion, $E$. faecium was the most prevalent species. The entire isolates set were MDR and the plasmid-carried aminoglycoside resistance genes were extensively disseminated among MDR isolates. Thus, regular surveillance studies, from the area of study or other geographical regions in Egypt, and strict infection control measures are required to monitor the emerging MDR enterococci.
\end{abstract}

Keywords: Enterococcus spp., aminoglycoside, vancomycin, biofilm, virulence

*Correspondence: nagwan.elmenofy@azhar.edu.eg

(Received: May 21, 2020; accepted: September 17, 2020)

Citation: Tawfick MM, El Menofy NG, Omran ME, Alsharony OA, Abo-Shady MA. Phenotypic and Molecular Characterization of Plasmid-Mediated Virulence and Antimicrobial Resistance Traits among Multidrug Resistant Enterococcus Spp. in Egypt. J Pure Appl Microbiol. 2020;14(3):1649-1661. doi: 10.22207/JPAM.14.3.03

(C) The Author(s) 2020. Open Access. This article is distributed under the terms of the Creative Commons Attribution 4.0 International License which permits unrestricted use, sharing, distribution, and reproduction in any medium, provided you give appropriate credit to the original author(s) and the source, provide a link to the Creative Commons license, and indicate if changes were made. 


\section{INTRODUCTION}

Enterococci are ubiquitous Gram-positive bacteria that naturally reside in the mouth and the gastrointestinal tract of the human being ${ }^{1}$. However, Enterococcus spp. have become important causes of healthcare-associated infections, for instance, endocarditis, septicaemia and infections of the urinary tract, in addition to the respiratory tract and skin infections $s^{2-4}$. Both E. faecium and E. faecalis are responsible for most human infections caused by Enterococcus spp., while other species are identified as well ${ }^{5,6}$. Notably, high-level resistance in enterococci to diverse classes of antimicrobial drugs, particularly the common clinically used glycopeptide antibiotics (e.g. vancomycin) and aminoglycosides, have become a significant problem; making the treatment of Enterococcus infections a challenge for clinicians ${ }^{7-10}$. Enterococcus bacteria have several virulence traits that enable various stages in the pathogenesis process. For instance, virulence factors help in bacterial adhesion and attack of the host cells and modulating the host defences along with the production of extracellular enzymes and toxins ${ }^{11}$. Such virulence factors include capsule formation, the Enterococcus surface protein (Esp), aggregation substance and gelatinase enzyme which play important roles in establishing a biofilm on the abiotic surfaces in health care setting $5^{5,11}$. Significantly, the changing epidemiology of Enterococcus spp. and their antimicrobial resistance profiles require identifying enterococci isolates at the species level and their antimicrobial resistance patterns for optimal treatment and infection control measures. Accordingly, the current study studied the incidence and the antimicrobial susceptibilities of enterococcal isolates from Egyptian hospitals and study the distribution of the high-level of aminoglycoside resistance among these isolates. The plasmid-carried antimicrobial resistance determinants genes such as genes encoding aminoglycoside-modifying enzymes (aac $\left(6^{\prime}\right)$ $\left.a p h\left(2^{\prime}\right), a p h(3)-I I I a\right)$ and vancomycin resistance gene vanA, in addition to the frequency of the genes encode the plasmid-mediated virulence factors including aggregation encoding gene agg and cytolysin biosynthesis encoding gene cylA were studied among Enterococcus spp. isolates collected in this study.

\section{METHODOLOGY}

Enterococci isolates and species identification

The clinical isolates of Enterococcus spp., in this study, were recovered from 240 various clinical samples including 92 urine samples, 91 pus samples and 57 blood samples. These samples were routinely collected and processed by the dedicated team through the medical care of patients in four Egyptian hospitals in Cairo including Homiat Elabasia Hospital, Elsayed Galal University Hospital, El Hussien University Hospital and Helwan General Hospital, over the period from November 2015 to March 2017. The study was approved by the ethical committee of the Faculty of Pharmacy (Girls), Al-Azhar University. The Enterococcus isolates were identified by Gram stain, cultural characteristics on different microbiological media such as cysteine, lactose, and electrolyte-deficient (CLED) agar (CONDA, Madrid, Spain), Bile Esculin agar (CONDA, Madrid, Spain), HiCrom UTI agar (HiMedia, Mumbai, India), in addition to biochemical testing. The different species of Enterococcus were identified using the KB005A HiStrep ${ }^{\mathrm{TM}}$ Identification Kit (HiMedia, Mumbai, India) based on the biochemical activities of enterococci isolates ${ }^{12}$.

Antibacterial susceptibility testing and determination of high-level aminoglycoside resistance

Antibacterial susceptibility testing of different Enterococcus spp. isolates was performed using the modified Kirby-Bauer disc diffusion method on Muller-Hinton agar (Oxoid, Hampshire, UK). Antimicrobial susceptibility profiles were determined according to the guidelines and interpretive criteria of Clinical Laboratory Standards Institute: Performance Standards of Antimicrobial Susceptibility Testing $(C L S I)^{13}$. The antimicrobial discs used in this study were the product of Oxoid (Hampshire, UK). The tested antimicrobials were ampicillin (AMP) $10 \mu \mathrm{g} /$ disc, chloramphenicol (C) $30 \mu \mathrm{g} /$ disc, ciprofloxacin (CIP) $5 \mu \mathrm{g} /$ disc, tobramycin (TOB) $15 \mu \mathrm{g} /$ disc, nitrofurantoin (F) $300 \mu \mathrm{g} /$ disc, rifampicin (RD) $5 \mu \mathrm{g} /$ disc, tetracycline (TE) $30 \mu \mathrm{g} /$ disc, vancomycin (VA) $30 \mu \mathrm{g} /$ disc, teicoplanin (TEC) $30 \mu \mathrm{g} /$ disc and linezolid (LNZ) $30 \mu \mathrm{g} /$ disc. The susceptibility to each vancomycin and teicoplanin was further confirmed by the broth microdilution method according to CLSI to determine MIC [13]. 
Screening for high-level aminoglycoside resistance by determination of both high-level gentamicin resistance (HLGR) and high-level streptomycin resistance (HLSR), was performed using high-level gentamicin (HLG) discs (120 $\mathrm{mg} /$ disc) and high-level streptomycin (HLS) disc (300 $\mathrm{\mu g} /$ disc).

Phenotypic assays for determination of virulence traits

Cytolysin production

Detection of blood haemolysis capability due to cytolysin production was performed according to Chow et al. ${ }^{14}$.

\section{Gelatinase production assay}

Gelatinase activity was investigated according to the study of Pollack et al. ${ }^{15}$.

\section{Biofilm formation assay}

The ability of biofilm formation was assayed by the microtiter plate method according to Mohamed et al. ${ }^{16}$ Optical density (OD) of stained adherent biofilm was determined using ELISA auto reader (Model 680, Biorad, UK) at a wavelength of $570 \mathrm{~nm}$. This assay was performed in triplicate wells and three independent repeats. The result of biofilm formation assay was interpreted as follows: if mean of the three repeats OD readings $\leq \mathrm{ODC}(3 \times \mathrm{SD}+$ mean OD of the negative control), it was considered as a non-biofilm producer, and if $\mathrm{ODc}<\mathrm{OD} \leq 2 \times \mathrm{ODc}$, it was considered as weak biofilm producer, if $2 \times O D C<O D \leq 4 \times O D c$, it was considered as moderate biofilm producer and if $4 \times O D c<O D$, it was considered as strong biofilm producer. Staphylococcus aureus ATTCC 29213 was the positive control in this assay and the negative control was sterile tryptic soy broth (TSB) ${ }^{17}$.

Plasmid DNA extraction and detection of purified plasmids

Overnight cultures of the 50 Enterococcus isolates were pelleted by centrifugation at 14, 000 for 2 minutes and suspended in $500 \mu \mathrm{l}$ normal saline solution. A volume of $100 \mu \mathrm{l}$ of $30 \mathrm{mg} / \mathrm{ml}$ lysozyme solution (L6876; Sigma, Milwaukee, USA) was added to the cell suspension and incubated for $30 \mathrm{~min}$ at $37^{\circ} \mathrm{C}$ with occasional mixing. The suspension was centrifuged ( $14000 \mathrm{rpm}$ ) at $25^{\circ} \mathrm{C}$ for $1 \mathrm{~min}^{18}$. Plasmid DNA was extracted from the pellets using Gene JET ${ }^{\mathrm{TM}}$ Plasmid Miniprep Kit (Thermo Scientific, Waltham, USA) according to the manufacturers' instructions. DNA preparations were stored in small aliquots at $-20^{\circ} \mathrm{C}$ and used as a template in PCR amplification. The extraction of plasmid DNA from all isolates was then analysed as the extracted DNA solution was subjected to electrophoresis on a $0.8 \%$ agarose gel (Bioline, London, UK). After electrophoresis, plasmid DNA bands were visualized by UV-transilluminator (Vilber Lourmant, Collégien, France).

Polymerase chain reactions (PCR)-based molecular study of antimicrobial resistance and virulence factors encoding genes

PCR screening was employed for detection of the plasmid-carried genes $a a c\left(6^{\prime}\right)$-aph(2'), $a p h(3)$ IIIa, vanA, agg and cylA which encode for $\operatorname{AAC}\left(6^{\prime}\right)$ / $\operatorname{APH}\left(2^{\prime}\right): 6^{\prime}$-aminoglycoside $\mathrm{N}$-acetyltransferase and 2'-aminoglycoside phosphotransferase, aminoglycoside O-phosphotransferase APH(3')IIla, vancomycin resistance, aggregation substance and cytolysin, respectively ${ }^{19-21}$. For PCR assays, the oligonucleotide primers sequences, synthesized by Thermo Scientific (Waltham, Massachusetts, USA), and the size of PCR amplicons of tested genes are recorded in Table 1 . PCR was carried out in reaction volume of $20 \mu$ containing $10 \mu$ l of Master Mix 2× (Promega, Madison, Wisconsin, USA), $1 \mu$ l of each primer (equivalent to concentration 10

Table 1. PCR oligonucleotide primers used in the study

\begin{tabular}{|c|c|c|c|}
\hline Target gene & Primer sequence $\left(5^{\prime}-3^{\prime}\right)$ & Amplicon size & Reference \\
\hline \multirow[t]{2}{*}{$\operatorname{aac}\left(6^{\prime}\right) \operatorname{aph}\left(2^{\prime \prime}\right)$} & F: CCAAGAGCAATAAGGGCATA & & \\
\hline & R: CACTATCATAACCACTACCG & $222 \mathrm{bp}$ & Ferretti et al. [19] \\
\hline \multirow{2}{*}{$a p h(3)-I I l a$} & F: GGCTAAAATGAGAATATCACCGG & & \\
\hline & R: CTTTAAAAAATCATACAGCTCGCG & $523 \mathrm{bp}$ & Vakulenko et al. [20] \\
\hline \multirow[t]{2}{*}{$a g g$} & F: AAGAAAAAGAAGTAGACCAAC & & \\
\hline & R: AAACGGCAAGACAAGTAAATA & $1553 \mathrm{bp}$ & Hashem et al. [21] \\
\hline \multirow[t]{2}{*}{ CylA } & F: TGGCGGTATTTTTTACTGGAG & & \\
\hline & R: TGAATCGCTCCATTTCTTC & $186 \mathrm{bp}$ & \\
\hline \multirow[t]{2}{*}{ vanA } & F: GGGAAAACGACAATTGC & & \\
\hline & R: GTACAATGCGGCCGTTA & 732 bp & \\
\hline
\end{tabular}


pmol), $2 \mu$ of plasmid DNA as a template DNA and completed to final volume by nuclease-free water (Promega, Madison, Wisconsin, USA). The PCR amplifications were performed in Veriti Thermal Cycler (Applied Biosystems, Foster City, California, USA) programmed for an initial denaturation at $95^{\circ} \mathrm{C}$ for 5 min and 40 cycles of denaturation at $95^{\circ} \mathrm{C}$ for $30 \mathrm{~s}$, primers annealing for $30 \mathrm{~s}$ at $50^{\circ} \mathrm{C}$ for the genes $\operatorname{aac}\left(6^{\prime}\right)$-aph (2"), vanA and $c y / A$, at $52^{\circ} \mathrm{C}$ for $a p h(3)$-IIla gene and at $48^{\circ} \mathrm{C}$ for agg gene, and extension at $72^{\circ} \mathrm{C}$ for 30 $s$ in case of the genes $\left(\operatorname{aac}\left(6^{\prime}\right)-a p h\left(2^{\prime \prime}\right)\right.$ and $\left.c y / A\right)$, for $45 \mathrm{~s}$ for aph(3)-Illagene, for $90 \mathrm{~s}$ for agg gene, and $50 \mathrm{~s}$ for vanA gene, then a final extension for $7 \mathrm{~min}$ at $72^{\circ} \mathrm{C}$. PCR products were detected through TAE (Tris-acetate-EDTA) agarose gel (1\%) electrophoresis prepared using molecular biology grade agarose (Bioline, Londona, UK) in 1x TAE buffer (Thermo Scientific, Waltham, Massachusetts, USA) containing ethidium bromide (Alliance Bio, Bothell, Washington, USA). DNA fragments were visualized and photographed by placing on a UV transilluminator (UVP, LLC, Upland, California, USA). GeneRuler 1 kb DNA molecular weight marker (Thermo Scientific, Waltham, Massachusetts, USA) was used to analyse the size of PCR amplicons.

\section{Statistical analysis}

Results were statistically analysed using SPSS software (version 14.0, Chicago, IL, USA).
The $P$-value of less than 0.05 was considered as statistically significant. The correlation between different virulence factors and biofilm formation was evaluated by the Chi-Square $(x 2)$ test.

\section{RESULTS}

Species distribution and antimicrobial susceptibility profiles of Enterococcus isolates

In this study, 50 clinical isolates of enterococci were collected which were recovered from 240 diverse clinical samples with a prevalence rate of $50 / 240(20.8 \%)$. The 50 isolates set included isolates from urine $(21 / 50,42 \%)$, pus $(17 / 50,34 \%)$ and blood $(12 / 50,24 \%)$. Based on the identification procedures used, five different Enterococcus species were identified among collected isolates. The most predominant species was $E$. faecium followed by $E$. faecalis representing $23(46 \%)$ and 15 (30\%) of total Enterococcus isolates, respectively. The other Enterococcus species were E. pseudoavium (6/50,12\%), E. avium $(3 / 50,6 \%)$ and $E$. raffinosus $(3 / 50,6 \%)$.

Study of the antimicrobial resistance profiles of the tested isolates showed that all isolates showed resistance to ampicillin, ciprofloxacin, tetracycline, rifampicin and tobramycin, while $68 \%, 48 \%, 80 \%, 56 \%$ and $8 \%$ of the entire isolates collection were resistant to high-level streptomycin, high-level gentamicin, chloramphenicol, nitrofurantoin and linezolid,

\section{Biofilm production among Enterococcus spp.}
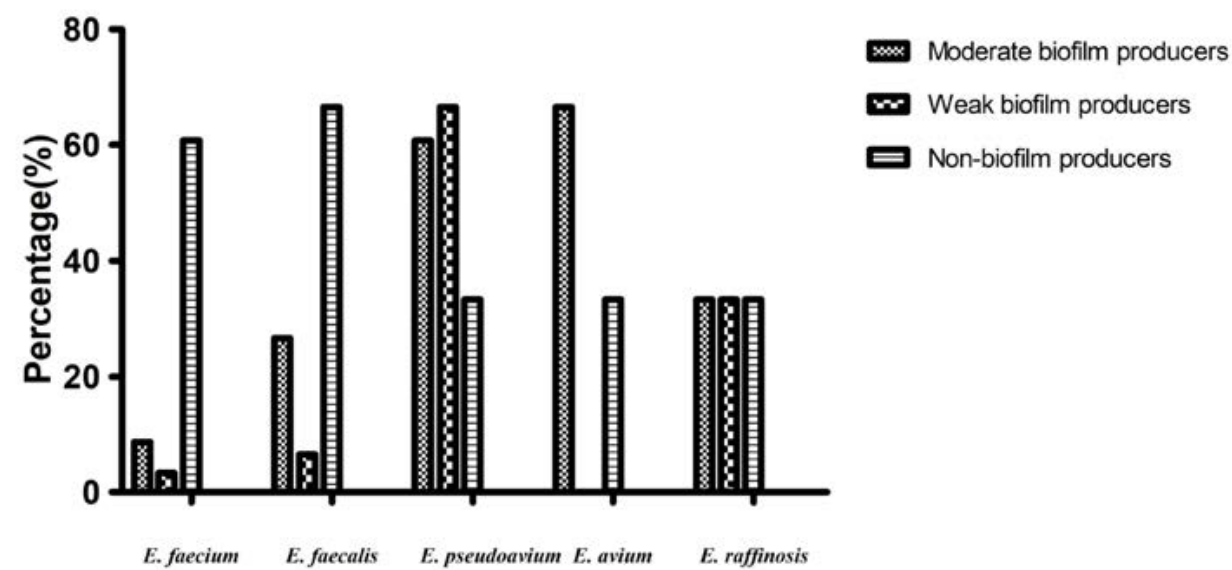

\section{Enterococcus spp.}

Fig. 1. Biofilm formation ability of Enterococcus spp. included in the study. 
respectively. The 50 isolates were sensitive to teicoplanin by either disc diffusion method or MIC determination. Antimicrobial susceptibility results are listed in Table 2. Concerning resistance to vancomycin, although disc diffusion method indicated resistance to vancomycin, MIC determination, using the broth microdilution assay, indicated the sensitivity of all isolates as MIC values were $\leq 4 \mu \mathrm{g} / \mathrm{ml}$ except one $E$. faecium isolate which showed intermediate resistance to vancomycin (MIC $=8 \mu \mathrm{g} / \mathrm{ml}$ ). Resistance to teicoplanin was also studied by determining MIC using the broth microdilution assay. These assays indicated that all isolates were sensitive to teicoplanin with MIC $\leq 1 \mu \mathrm{g} / \mathrm{ml}$.

Phenotypic detection of some virulence traits The phenotypic assays performed in this study revealed the expression of the

Table 2. Antimicrobial susceptibility patterns of the isolated Enterococcus spp.

\begin{tabular}{|c|c|c|c|c|c|c|c|c|}
\hline $\begin{array}{l}\text { Antimicrobial } \\
\text { agent }\end{array}$ & & & $\begin{array}{l}\text { E. avium } \\
\qquad(3)^{\mathrm{a}}\end{array}$ & $\begin{array}{c}\text { E. faecalis } \\
(15)^{a}\end{array}$ & $\begin{array}{l}\text { E. fecium } \\
(23)^{\mathrm{a}}\end{array}$ & $\begin{array}{l}\text { E. pseudoavium } \\
(6)^{\mathrm{a}}\end{array}$ & $\begin{array}{l}\text { E. raffinosis } \\
(3)^{\mathrm{a}}\end{array}$ & $\begin{array}{c}\text { Total } \\
\text { Resistance } \\
(\%)^{\mathrm{b}}\end{array}$ \\
\hline \multirow[t]{4}{*}{ HLGR* } & \multirow[t]{2}{*}{$S$} & No. & 1 & 8 & 12 & 3 & 2 & \multirow[t]{4}{*}{$24(48 \%)$} \\
\hline & & $\%$ & $33.3 \% b$ & $53.30 \%$ & $52.20 \%$ & $50 \%$ & $66.70 \%$ & \\
\hline & \multirow[t]{2}{*}{$\mathrm{R}$} & No. & 2 & 7 & 11 & 3 & 1 & \\
\hline & & $\%$ & $66.60 \%$ & $46.70 \%$ & $47.80 \%$ & $50 \%$ & $33.30 \%$ & \\
\hline \multirow[t]{4}{*}{ HLSR* } & \multirow[t]{2}{*}{$S$} & No. & 0 & 5 & 10 & 1 & 0 & \multirow[t]{4}{*}{$34(68 \%)$} \\
\hline & & $\%$ & $0 \%$ & $33.30 \%$ & $43.50 \%$ & $16.70 \%$ & $0 \%$ & \\
\hline & \multirow[t]{2}{*}{$\mathrm{R}$} & No. & 3 & 10 & 13 & 5 & 3 & \\
\hline & & $\%$ & $100 \%$ & $66.7 \%$ & $56.50 \%$ & $83.30 \%$ & $100 \%$ & \\
\hline \multirow[t]{4}{*}{ HLSR+ HLGR } & \multirow[t]{2}{*}{$S$} & No. & 2 & 9 & 15 & 3 & 2 & \multirow[t]{4}{*}{19 (38\%) } \\
\hline & & $\%$ & $66.60 \%$ & $60 \%$ & 65.2 & $50 \%$ & $66.70 \%$ & \\
\hline & \multirow[t]{2}{*}{$\mathrm{R}$} & No. & 1 & 6 & 8 & 3 & 1 & \\
\hline & & $\%$ & $33.30 \%$ & $40 \%$ & 34.8 & $50 \%$ & $33.30 \%$ & \\
\hline \multirow[t]{4}{*}{ Linezolid } & \multirow[t]{2}{*}{$S$} & No. & 3 & 13 & 21 & 6 & 3 & \multirow[t]{4}{*}{$4(8 \%)$} \\
\hline & & $\%$ & $100 \%$ & $86.70 \%$ & $91.30 \%$ & $100 \%$ & $100 \%$ & \\
\hline & \multirow[t]{2}{*}{$\mathrm{R}$} & No. & 0 & 2 & 2 & 0 & 0 & \\
\hline & & $\%$ & $0 \%$ & $13.30 \%$ & $8.70 \%$ & $0 \%$ & $0 \%$ & \\
\hline \multirow[t]{4}{*}{ Nitrofurantoin } & \multirow[t]{2}{*}{$S$} & No. & 1 & 9 & 7 & 4 & 1 & \multirow[t]{4}{*}{$28(56 \%)$} \\
\hline & & $\%$ & $33.30 \%$ & $60 \%$ & $30.40 \%$ & $66.70 \%$ & $33.30 \%$ & \\
\hline & \multirow[t]{2}{*}{$\mathrm{R}$} & No. & 2 & 6 & 16 & 2 & 2 & \\
\hline & & $\%$ & $66.60 \%$ & $40 \%$ & $69.60 \%$ & $33.30 \%$ & $66.70 \%$ & \\
\hline \multirow[t]{4}{*}{ Chloramphenicol } & \multirow[t]{2}{*}{$S$} & No. & 0 & 3 & 5 & 1 & 1 & \multirow[t]{4}{*}{$40(80 \%)$} \\
\hline & & $\%$ & $0 \%$ & $20 \%$ & $21.70 \%$ & $16.70 \%$ & $33.30 \%$ & \\
\hline & \multirow[t]{2}{*}{$\mathrm{R}$} & No. & 3 & 12 & 18 & 5 & 2 & \\
\hline & & $\%$ & $100 \%$ & $80 \%$ & $78.30 \%$ & $83.30 \%$ & $66.70 \%$ & \\
\hline \multirow[t]{4}{*}{ Teicoplanin } & \multirow[t]{2}{*}{$S$} & No. & 3 & 15 & 23 & 6 & 3 & \multirow[t]{4}{*}{$0(0 \%)$} \\
\hline & & $\%$ & $100 \%$ & $100 \%$ & $100 \%$ & $100 \%$ & $100 \%$ & \\
\hline & $\mathrm{R}$ & No. & 0 & 0 & 0 & 0 & 0 & \\
\hline & & $\%$ & $0 \%$ & $0 \%$ & $0 \%$ & $0 \%$ & $0 \%$ & \\
\hline Ciprofloxacin & $S$ & No. & 0 & 0 & 0 & 0 & 0 & \\
\hline Tetracycline & & $\%$ & $0 \%$ & $0 \%$ & $0 \%$ & $0 \%$ & $0 \%$ & \\
\hline Ampicillin & & & & & & & & $50(100 \%)$ \\
\hline Rifampicin & $R$ & No. & 3 & 15 & 23 & 6 & 3 & \\
\hline Tobramycin & & $\%$ & $100 \%$ & $100 \%$ & $100 \%$ & $100 \%$ & $100 \%$ & \\
\hline Vancomycin & & & & & & & & \\
\hline
\end{tabular}

*Abbreviations: S, sensitive; R, resistant; HLSR, high-level streptomycin resistance; HLGR, high-level gentamycin resistance; a) total number of isolates related to each species; b) percentage correlated to the number of isolates related to each species; c) percentage correlated to the number of isolates ( 50 isolates). 


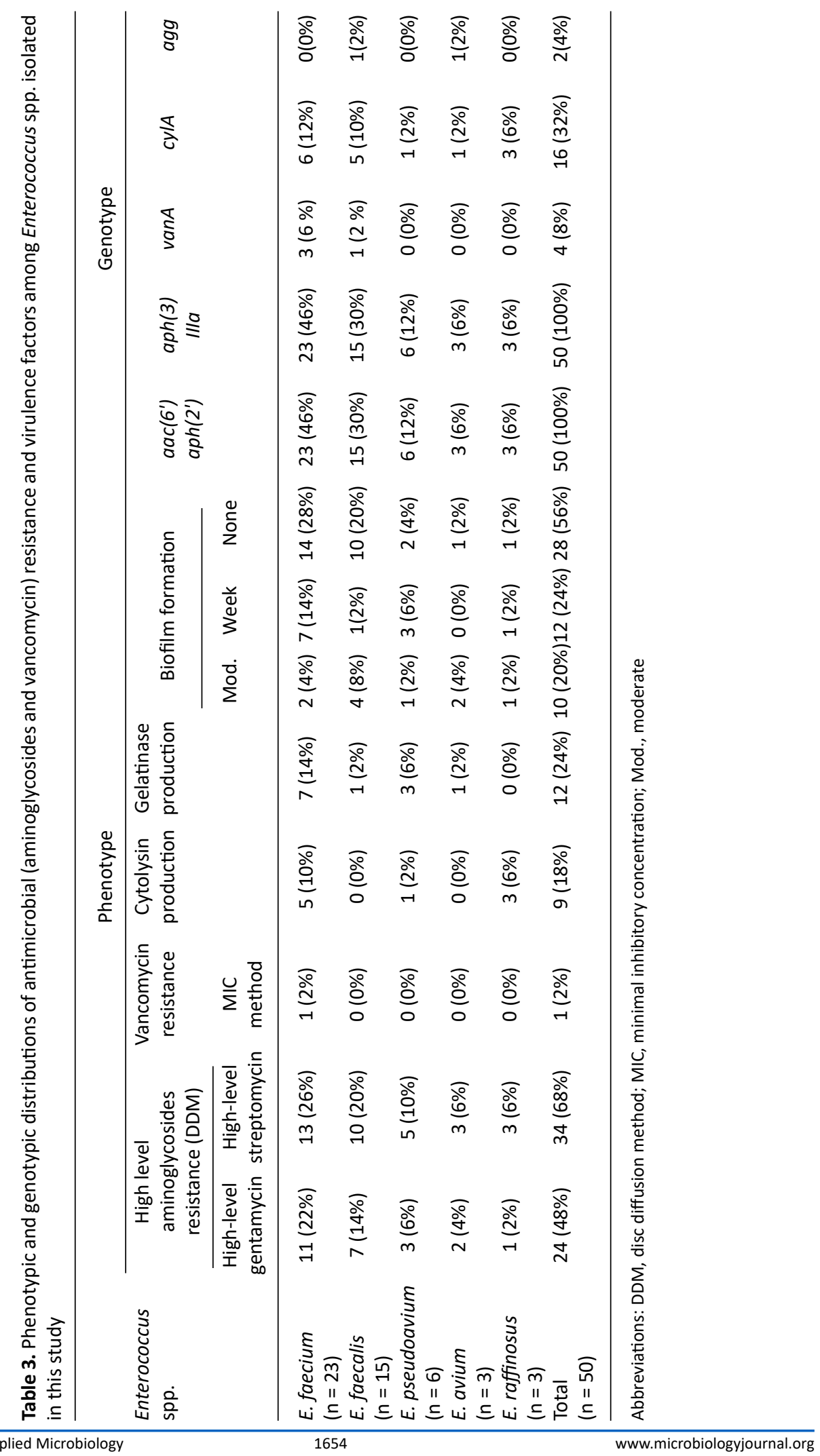


studied virulence factors by some Enterococcus isolates. The blood haemolysis assays revealed the production of cytolysin by 9 isolates (18\%) as they showed complete $(\beta)$ haemolysis. All $E$. raffinosus isolates $(\mathrm{n}=3$ ), E. faecium isolates ( $\mathrm{n}$ $=5$ ) and one isolates of E. pseudoavium which represent $6 \%, 10 \%$ and $2 \%$ of total Enterococcus isolates produced this haemolytic effect (Table 3 ). Gelatinase enzyme production was detected in $12(24 \%)$ of Enterococcus isolates indicated by gelatine liquefaction. The 12 isolates comprised 7 isolates of Enterococcus faecium (14\%), 3 isolates of E. pseudoavium (6\%) and 2 isolates of E. faecalis and E. avium (4\%) (Table 3).

The ability of biofilm formation testing revealed that $10(20 \%)$ isolates were moderate biofilm producers, $12(24 \%)$ isolates were weak biofilm producers and $28(56 \%)$ isolates did not have the ability for biofilm formation (Table 3, Fig. 1). Moderate biofilm-forming bacteria were mostly among isolates recovered from urine samples ( $40 \%)$, followed by those recovered from blood and pus samples represented (30\%) within each specimen type. Out of 10 moderate biofilm producers, $4(8 \%)$ isolates were Enterococcus faecium and 2(4\%) were E. faecalis.

Plasmid analysis and the Prevalence of some plasmid -carried virulence and vancomycin and aminoglycosides resistance genes

Agarose gel electrophoresis-based analysis of the extracted plasmid DNA from 50 isolates indicated intact isolated plasmids in

Table 4. Correlation between the phenotypic and genotypic presence of virulence factors, vancomycin resistance gene and biofilm formation

\begin{tabular}{|c|c|c|c|c|}
\hline \multirow[t]{2}{*}{$\begin{array}{l}\text { Virulence factors } \\
+ \text { (positive phenotype) or - (negative } \\
\text { phenotype)/ (No. of isolates) }\end{array}$} & \multicolumn{3}{|c|}{$\begin{array}{l}\text { No. (\%) of isolates with } \\
\text { biofilm phenotype }\end{array}$} & \multirow[t]{2}{*}{$P$-value } \\
\hline & Medium & Weak & Total & \\
\hline Cytolysin production+ / (9) & 1 & 2 & 3 & 0.650 \\
\hline Cytolysin production /(41) & 9 & 10 & 19 & \\
\hline Gelatinase production+ / (12) & 4 & 4 & 8 & 0.746 \\
\hline Gelatinase production- / (38) & 6 & 8 & 14 & \\
\hline$c y l A+/(16)$ & 4 & 3 & 7 & 0.769 \\
\hline cylA- /(34) & 6 & 9 & 15 & \\
\hline $\operatorname{vanA}+/(4)$ & 3 & 1 & 4 & 0.449 \\
\hline $\operatorname{van} A-/(46)$ & 7 & 11 & 18 & \\
\hline$a g g+/(2)$ & 1 & 0 & 1 & \\
\hline agg-/(48) & 9 & 12 & 21 & 0.925 \\
\hline
\end{tabular}

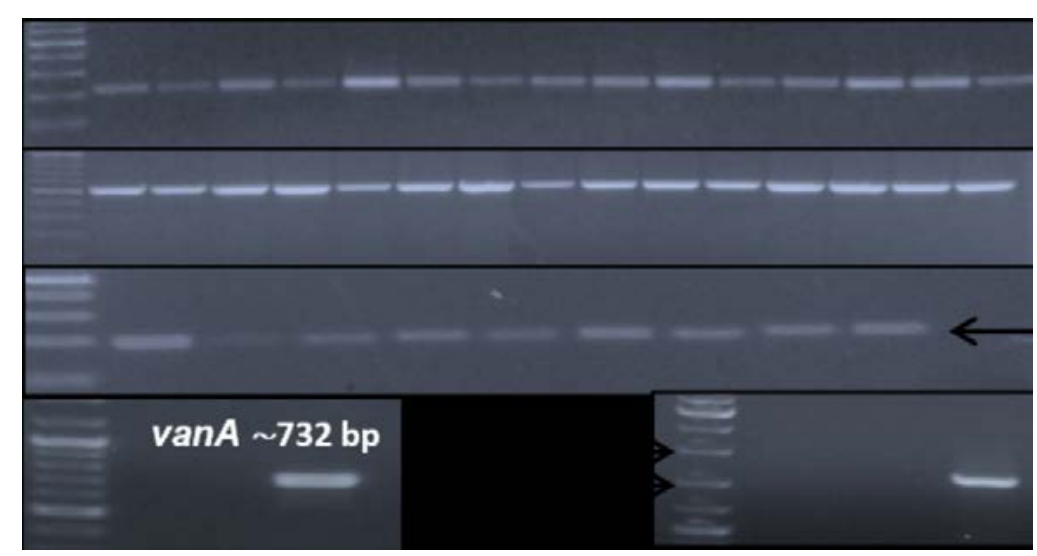

Fig. 2. Representative agarose gel (1\%) electrophoresis of PCR products of investigated plasmid-carried antimicrobial resistance and virulence factors encoding genes among enterococcal isolates. 
different patterns among isolates. PCR analyses of the extracted plasmid DNA exhibited the existence of aminoglycosides resistance genes $\operatorname{aac}\left(6^{\prime}\right)-a p h\left(2^{\prime}\right)$ and $a p h(3)-I I l a$ in all tested isolates $(100 \%)$, while vancomycin resistance gene vanA was detected in 4 isolates (8\%); three $E$. faecium isolates and one $E$. faecalis isolate. The distributions of the virulence genes agg and cylA were $4 \%$ and $32 \%$, respectively (Table 3, Fig. 2).

Correlation between biofilm-forming capacity and antimicrobial and virulence factors

The correlations between biofilm-forming ability and incidence of different antimicrobial or virulence factors encoding genes were insignificant as $\mathrm{P}>0.05$ (Table 4).

\section{DISCUSSION}

The MDR enterococci bacteria are emerging as a leading cause of healthcare opportunistic infections in hospitalized patients, mostly the immunocompromised ${ }^{22-25}$. Consequently, it is important to control and prevent the outbreak of Enterococcus infections by regular identification of the prevalence and antimicrobial resistance patterns of these bacteria ${ }^{26,27}$. The current study explored the prevalence and antimicrobial susceptibility of Enterococcus spp. in Cairo, Egypt. Furthermore, the study aimed to find some plasmid-mediated antimicrobial resistance and virulence factors encoding genes among isolated Enterococcus species and study the correlation between the antimicrobial and virulence factors phenotypes and/or the presence of their corresponding plasmid-carried genes.

In the current study, 50 Enterococcus isolates were recovered from 240 clinical samples representing $20.8 \%$ of bacterial isolates during the period of study. This frequency was almost like the frequencies reported in other geographical regions in Egypt as well as other countries such as Iran and Pakistan ${ }^{28-30}$.

Five different Enterococcus species were identified in the study. The most predominant species was $E$. faecium followed by $E$. faecalis representing $46 \%$ and $30 \%$ of total Enterococcus isolates, respectively. The other Enterococcus species identified in lower percentages were E. pseudoavium (12\%), E. avium (6\%) and $E$. raffinosus (6\%). These findings were consistent with other previous studies ${ }^{3,31}$. However, earlier studies in the same geographical region of the current study reported a high prevalence of $E$. faecalis over $E$. faecium ${ }^{21,32,33}$. Besides, regarding the type of clinical samples, the highest number of MDR Enterococcus isolates was recovered from urine samples. This finding is comparable to previous studies from Egypt as well as other countries ${ }^{10,28,32,33}$.

Study the antimicrobial susceptibilities designated all Enterococcus isolates as MDR being resistant to three or more diverse antimicrobial classes $^{34}$. Disc diffusion method revealed that all isolates were resistant to vancomycin, ciprofloxacin, tetracycline, ampicillin, rifampicin and tobramycin, While, resistance rates of $56.5 \%, 47.8 \%, 78.3 \%$, $69.6 \%$ and $4 \%$ among $E$. faecium isolates and 66 . $7 \%, 46.7 \%, 80 \%, 40 \%$ and $4 \%$ of $E$. faecalis isolates were recorded to high-level streptomycin, highlevel gentamicin, chloramphenicol, nitrofurantoin, and linezolid, respectively.

This high distribution of MDR Enterococcus spp., particularly in developing countries, is partly due to the widespread and misuse of antimicrobial drugs which consequently results in limitation in the therapeutic options ${ }^{35,36}$. In addition to the disc diffusion method, resistance to glycopeptides was determined by broth microdilution method as per CLSI recommendation ${ }^{13}$, since the disc test does not differentiate vancomycin-susceptible isolates from vancomycin-intermediate strains ${ }^{37}$. The 50 enterococcal isolates showed high sensitivity to teicoplanin by both disc diffusion and broth microdilution assay. These records were relatively comparable to other studies ${ }^{21,35,38-40}$.

Contrary to the disc diffusion method, which showed full vancomycin-resistant enterococci (VRE) profile; broth microdilution assay revealed only one $E$. faecium isolate had intermediate resistance pattern to vancomycin showing a Van $B$ phenotype since susceptible to teicoplanin by PCR we detected a plasmidic $\operatorname{van} A$ gene in this isolate, in other 3 strains still completely susceptible to vancomycin, these incongruent Enterococcus genotypes-phenotypes should be related to mutations or deletions in the VanA operons as previously described ${ }^{41-43}$.

Results suggested that both MIC and PCR should be taken into consideration in evaluating the susceptibility to vancomycin and identification of 
Vancomycin incongruence genotypes-phenotypes isolates, respectively and recommended the exclusion of vancomycin as therapy in patients were these isolates are detected.

The Plasmid carrying-vancomycin resistance gene vanA is common among Enterococcus isolates in Europe and the United States ${ }^{44}$. The low VRE occurrence here found (8\%) agreed with several studies in Cairo, Egypt that reported no or the same low frequency of VRE ${ }^{21,35,44}$. Strains like these capable of expressing resistance to vancomycin, if used is worrying, because these isolates are not revealed biochemically but only by molecular method.

Concerning aminoglycosides resistance in this study, HLGR and HLSR were observed in $48 \%$ and $68 \%$ of Enterococcus isolates, respectively, while $38 \%$ of isolates showed both HLGR and HLSR. The higher frequency of HLSR over HLGR in this study is inconsistent with previous studies where HLGR was more prevalent ${ }^{2,3,45,46}$ while it is agreed with another study ${ }^{47}$. That could be explained by the extensive use of gentamicin over streptomycin in the hospitals involved in the current study. Although, both findings designate that the resistance to streptomycin does not always correlate with resistance to gentamicin ${ }^{48}$.

Linezolid is the drug of choice for treatment of drug-resistant Enterococcus infections; however, the emergence of linezolid resistance in enterococci ${ }^{39}$. In the present study, fortunately, 4 (8\%) isolates only were resistant to linezolid, which was consistent with previous studies ${ }^{39,46}$.

Plasmid profile is main epidemiological tool to study genetic diversity and the dissemination of antimicrobial resistance among bacteria ${ }^{49}$. In this study, different patterns were detected among enterococcal isolates indicating diversity of isolates due to the higher exposure of people to Enterococcus spp. in this geographical area and/ or high rate of plasmid transfer amongst bacteria. The high-level of resistance to aminoglycosides among Enterococcus species is attributed to acquiring the extrinsic resistance genes encoding the aminoglycoside-modifying enzymes. HLGR and HLSR in enterococci are mostly mediated by the

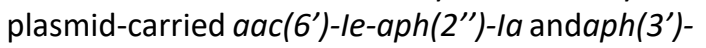
IIIa, respectively ${ }^{47}$. The PCR investigation of the plasmid-carried aminoglycoside resistance genes $\operatorname{aac}\left(6^{\prime}\right)-a p h\left(2^{\prime}\right)$ and $a p h(3)$-IIla in our study revealed the presence of both genes in all tested isolates (Table 3, Fig. 1). While the inconsistency between the phenotypic results and carrying of these genes is similar to the findings of another study in India ${ }^{50}$ where $26.02 \%$ of isolates were phenotypically resistant to high-level gentamicin, and $15 \%$ were resistant to high-level streptomycin, although $94.75 \%$ of isolates were carrier for aac (6')-le-aph (2")-la which encodes a very powerful bi-functional aminoglycosidemodifying enzymes resulted from the fusion of two genes. Other studies reported a high prevalence of aminoglycoside resistance that expressed phenotypically equivalent to the presence of the encoding genes $a a c\left(6^{\prime}\right)-l e-a p h\left(2^{\prime \prime}\right)-l a$ and $a p h\left(3^{\prime}\right)-111 a^{46,47}$. These findings might indicate that the phenotypic expression of HLGR or HLSR may require the presence of multiple aminoglycosides resistance mechanisms and/or genes other than targeted ones in our study. Also, it can be explained by the interaction among multiple genes involved in this trait and/or the environmental factors that can impact phenotype, besides some alleles may be silenced by other genes that minimize their expression.

HLGR and HLSR encoding genes are also found in Enterococcus spp. other than the most common species faecalis and faecium. Moreover, significantly, the coexistence of both genes was detected in all tested isolates which is the first time to be reported. This can be explained by the high possibility and dissemination of plasmid-mediated horizontal gene transfer among enterococci in the geographical area of this study, which leads to the rapid dispersion of resistance to aminoglycosides ${ }^{51}$. In the current study, $32 \%$ of Enterococcus isolates were positive for $C y / A$ gene although cytolysin production indicated by complete $(\beta)$ haemolysis was phenotypically observed in $18 \%$ of total isolates. All isolates showed $\beta$-haemolysis were carrier for $c y / A$ gene. These findings were consistent with a previous study where the percentage of phenotypic expression of cytolysin was $16.7 \% \%^{52}$ and with another study where the phenotypic and genotypic expression of cytolysin was $8 \%$ and $16 \%$, respectively ${ }^{21}$. The phenotypic expression of cytolysin was in lower frequency than that of the detected encoding gene. This could be attributed to the fact that the 
expression of cytolysin requires other proteins or factors encoded by genes on cy/L locus ${ }^{24}$. Each the phenotypic and genotypic profile of cytolysin was high among $E$. faecalis than in E. faecium isolates which agreed with previous studies ${ }^{11,21,53}$. Screening of biofilm formation capability among MDR isolates, $20 \%$ of isolates showed moderate biofilm production and $24 \%$ of isolates were weak biofilm producers while the remaining isolates (56\%) were non-biofilm producers. Out of $10(20 \%)$ moderate biofilm producers isolates; 4 were E. faecium. These records are less comparable to previous studies where a higher percentage of strong, medium and weak biofilm producers were documented ${ }^{32,54,55}$. This could be explained that their isolates were mostly recovered from urine which considered as one of the main sources in which biofilm can develop a severe problem. Biofilm can be formed in the urothelium, prostate stones and implanted foreign bodies $^{56}$. Aggregation substances $(a g g)$ mediate the transfer of mobile genetic elements and the formation of aggregates during conjugation ${ }^{57,58}$.

Only 2 (4\%) Enterococcus isolates (one E. faecalis isolate and one E. avium isolate) were carriers for agg gene in the current study; one of them was categorized phenotypically as moderate biofilm producer and the other was non-biofilm producer. This record is like the study of Hashem et al. ${ }^{21}$ from the same geographical region Cairo, Egypt, which recorded the frequency of $3 \%$ of agg gene. Conversely, other studies reported much higher frequencies where agg gene was carried by moderate and strong biofilm forming isolates ${ }^{3,54,59}$. Gelatinase action has been known as one of the initial steps in the biofilm formation ${ }^{57}$. In the current study, $24 \%$ of isolates were capable to hydrolyse gelatine indicated by gelatine liquefaction. This record was comparable with previous studies ${ }^{32,55,56}$.

There was no significant correlation between virulence factors investigated phenotypically and/or distribution of their encoding genes to biofilm formation, and between biofilm-forming capacity and incidence of other virulence factors was found to be statistically not significant $(P<0.05)$ calculated by Chi-Square $(\chi 2)$ test, although moderate and weak biofilm production was found to be frequently associated with gelatine liquefaction capability ${ }^{32,56}$.

\section{CONCLUSION}

Regular recent data on antimicrobial resistance profile is important for treatment guidelines for infections caused by MDR Enterococcus spp. The resistance of Enterococcus spp. to aminoglycosides is of great concern, since it limits the therapeutic options of serious Enterococcus infections even by the synergy with beta-lactam antibiotics. Thus, strict infection control measures in hospitals, as well as a public health strategy on the appropriate prescribing and the rational use of antimicrobial drugs must be followed to limit the spread of MDR enterococci. Besides, more reliable screening of Enterococcus isolates for vancomycin resistance would be considered including the recommended MIC tests over the disc diffusion method. Consequently, it should be taken into consideration in evaluating the susceptibility to vancomycin that depending only on the disc diffusion test may result in the exclusion of this effective antibiotic from the empirical antibiotic therapy. while it is recommended that MIC tests should be performed to determine the susceptibility to vancomycin. Furthermore, molecular detection should be used to detected vancomycin susceptible Enterococci carrying low or unexpressed van genes.

\section{ACKNOWLEDGMENTS}

None.

\section{CONFLICT OF INTEREST}

The authors declare that there is no conflict of interest.

\section{AUTHORS' CONTRIBUTION}

All authors designed the experiments. MMT, NGE and OAA performed the experiments. MMT, NGE, MEO and OAA analysed the data. MMT, NGE, MEO and OAA and MAA wrote and revised the manuscript. All authors read and approved the manuscript.

\section{FUNDING}

None.

\section{ETHICS STATEMENT}

This article does not contain any studies with human participants or animals performed by any of the authors. 


\section{DATA AVAILABILITY}

All datasets generated or analysed during this study are included in the manuscript.

\section{REFERENCES}

1. Akhter J, Ahmed S, Saleh AA, Anwar S. Antimicrobial resistance and in vitro biofilm-forming ability of Enterococci spp. isolated from urinary tract infection in a tertiary care hospital in Dhaka. Bangladesh Med Res Counc Bull. 2014;40(3):6-9. doi: 10.3329/bmrcb. v40i1.20320

2. Agarwal J, Kalyan R, Singh M. High-level aminoglycoside resistance and Beta-lactamase production in enterococci at a tertiary care hospital in India. Jpn J Infect Dis. 2009;62(2):158-9.

3. Niu H, Yu H, Hu T, et al. The prevalence of aminoglycoside-modifying enzyme and virulence genes among enterococci with high-level aminoglycoside resistance in Inner Mongolia, China. Brazil J Microbiol. 2016;47(3):69-696. doi: 10.1016/j.bjm.2016.04.003

4. Kilbas I, Ciftci IH. Antimicrobial resistance of Enterococcus isolates in Turkey: a meta-analysis of current studies. J Glob Antimicrob Resist. 2018;12:2630. doi: 10.1016/j.jgar.2017.08.012

5. Biswas PP, Dey S, Adhikari L, Sen A. Virulence markers of vancomycin resistant enterococci isolated from infected and colonized patients. J Glob Infect Dis. 2014;6(4):157-163. doi: 10.4103/0974-777X.145242

6. rieto $A M G$, van Schaik W, Rogers MR, et al. Global emergence and dissemination of enterococci as nosocomial pathogens: attack of the clones. Front Microbiol. 2016;7:788. doi: 10.3389/fmicb.2016.00788

7. Corso AC, Gagetti PS, Rodriguez MM, et al. VRE Argentinean Collaborative Group. Molecular epidemiology of vancomycin-resistant Enterococcus faecium in Argentina. Int J Infect Dis. 2007;11(1):69-75. doi: 10.1016/j.ijid.2006.02.003

8. Lambiase A, Del Pezzo M, Piazza O, Petagna C, De Luca C, Rossano F. Typing of vancomycin-resistant Enterococcus faecium strains in a cohort of patients in an Italian intensive care unit. Infection. 2007;35(6):428433. doi: 10.1007/s15010-007-6288-4

9. Nasonova ES. Pulsed field gel electrophoresis: theory, instruments and applications. Tsitologiia. 2008;50(11):927-935. doi: 10.1134/ S1990519X08060011

10. Saeidi S, Mirnejad R, Zavaryani SM, Rostamzadeh S. Molecular epidemiology and antibiotic resistance patterns of Enterococcus faecalis isolates from hospitals in Tehran. Infez Med. 2017;25(2):116-122.

11. Strateva T, Atanasova D, Savov E, Petrova G, Mitov I. Incidence of virulence determinants in clinical Enterococcus faecalis and Enterococcus faecium isolates collected in Bulgaria. Braz J Infect Dis. 2016;20(7):127-133. doi: 10.1016/j.bjid.2015.11.011

12. Patidar V, Saraf G, Sharma A, Mehata P, Sharma G. Prevalence of Enterococcus infections and their antibiotic susceptibility pattern with special reference to HLAR in south east Rajasthan. J Evolution Med Dent Sci. 2016;5(35):1973-1975. doi: 10.14260/ jemds/2016/466
13. Clinical and Laboratory Standards Institute. Performance Standards for Antimicrobial Susceptibility Testing. Twenty-sixth Informational Supplement. CLSI document M100-S26. Wayne, PE: Clinical and Laboratory Standards Institute; Available from: www. facm.ucl.ac.be/intranet/CLSI/CLSI-2016-M100-S26.pdf 14. Chow JW, Thal LA, Perri MB, et al. Plasmid-associated haemolysin and aggregation substance production contribute to virulence in experimental enterococcal endocarditis. Antimicrob Agents Chemother. 1993;37(11):2474-7. doi: 10.1128/AAC.37.11.2474

15. Pollack R, Lorraine F, Walter M, Modesto R. Laboratory exercises in microbiology. $4^{\text {th }}$ edition. USA: Wiley \& Sons, Inc. 2012:288

16. Mohamed JA, Huang W, Nallapareddy SR, Teng F, Murray BE. Influence of origin of isolates, especially endocarditis isolates, and various genes on biofilm formation by Enterococcus faecalis. Infect Immun. 2004;72(6):3658-3663. doi: 10.1128/IAI.72.6.36583663.2004

17. Bocanegra-Ibarias $\mathrm{P}$, Flores-Trevino $\mathrm{S}$, Camacho-Ortiz $A$, et al. Phenotypic and genotypic characterization of vancomycin-resistant Enterococcus faecium clinical isolates from two hospitals in Mexico: First detection of VanB phenotype-vanA genotype. Enferm Infecc Microbiol Clin. 2016;34(7):415-421. doi: 10.1016/j. eimc.2015.09.011

18. Ulrich RL, Hughes TA. A rapid procedure for isolating chromosomal DNA from Lactobacillus species and other Gram-positive bacteria. Lett Appl Microbiol. 2001;32(1):52-56. doi: 10.1046/j.1472765x.2001.00866.x

19. Ferretti JJ, Gilmore KS, Courvalin P. Nucleotide sequence analysis of the gene specifying the bifunctional 6 '-aminoglycoside acetyltransferase 2 "-aminoglycoside phosphotransferase enzyme in Streptococcus faecalis and identification and cloning of gene regions specifying the two activities. J Bacteriol. 1986;167(2):631-638. doi: 10.1128/JB.167.2.631638.1986

20. Vakulenko SB, Donabedian SM, Voskresenskiy AM, Zervos MJ, Lerner SA, Chow JW. Multiplex PCR for detection of aminoglycoside resistance genes in enterococci. Antimicrob Agents Chemother. 2003;47(4):1423-1426. doi: 10.1128/AAC.47.4.14231426.2003

21. Hashem YA, Yassin AS, Amin MA. Molecular characterization of Enterococcus spp. clinical isolates from Cairo, Egypt. Indian J Med Microbiol. 2015;33(5):80-86. doi: 10.4103/0255-0857.148836

22. Furtado GH, Martins ST, Coutinho AP, Wey SB, Medeiros EA. Prevalence and factors associated with rectal vancomycin-resistant enterococci colonization in two intensive care units in Sao Paulo, Brazil. Braz J Infect Dis. 2005;9(1):64-69. doi: 10.1590/S141386702005000100011

23. Carlet J, Jarlier V, Harbarth S, Voss A, Goossens H, Pittet D. Ready for a world without antibiotics? The Pensieres antibiotic resistance call to action. Antimicrob Resist Infect Control. 2012;1(11):1-13. doi: 10.1186/20472994-1-11

24. Chajecka-Wierzchowska W, Zadernowska A, Laniewska- 
Trokenheim L. Virulence factors of Enterococcus spp. presented in food. LWT-Food Sci Technol. 2017;75:670676. doi: 10.1016/j.Iwt.2016.10.026

25. Kristich CJ, Rice LB, Arias CA. Enterococcus infectiontreatment and antibiotic resistance. 2014:87-134. In Enterococci: Gilmore MS, Clewell DB, Ike Y, et al., (eds.). From Commensals to Leading Causes of Drug Resistant Infection. Boston: Massachusetts Eye and Ear Infirmary, Inc. Available from: https://www.ncbi. nlm.nih.gov/books/NBK190420/.

26. Willems RJ, Bonten MJ. Glycopeptide- resistant enterococci: deciphering virulence, resistance and epidemicity. Curr Opin Infect Dis. 2007;20(4):384-390. doi: 10.1097/QCO.0b013e32818be63d

27. Ryan L, O'Mahony E, Wrenn C, et al. Epidemiology and molecular typing of VRE bloodstream isolates in an Irish tertiary care hospital. J Antimicrob Chemother. 2015;70:2718-2724. doi: 10.1093/jac/dkv185

28. Ghonaim M, Ghoniem E, Abdulaziz A, Abd Elmotaleb T. Enterococci in hospital associated infection in the national liver institute, Egypt. Egy J Med Microbiol. 2009;18:69-79.

29. Hajia M, Rahbar M, Zadeh MM. A novel method "CHROMagar" for screening vancomycin-resistant Enterococci (VRE) isolates. Afr J Biotechnol. 2012;14(41):9865-9868. doi: 10.5897/AJB12.328

30. Gul Z, Jan AZ, Liaqat F, Qureshi MS. Causative organisms and antimicrobial sensitivity pattern of paediatric urinary tract infection. Gomal J Med Sci. 2015;13(2):118-122.

31. Worth LJ, Slavin MA, Vankerckhove V, Goossens H, Grabsch EA, Thursky K. Virulence determinants in vancomycin-resistant Enterococcus faecium van B: clonal distribution, prevalence and significance of esp and hyl in Australian patients with haematological disorders. J Hosp Infect. 2008;68(2):137-144. doi: 10.1016/j.jhin.2007.10.017

32. Hashem YA, Amin HM, Essam TM, Yassin AS, Aziz RK. Biofilm formation in enterococci: genotype-phenotype correlations and inhibition by vancomycin. Sci Rep. 2017;7(1):5733-5745. doi: 10.1038/s41598-01705901-0

33. Hassan RM, Ghaith DM, Ismail D, Zafer MM. Reduced susceptibility of Enterococcus spp. isolates from Cairo University Hospital to tigecycline: Highlight on the influence of proton pump inhibitors. J Glob Antimicrob Resist. 2018;12:68-72. doi: 10.1016/j.jgar.2017.12.005

34. Magiorakos AP, Srinivasan A, Carey RB, et al. Multidrug-resistant, extensively drug-resistant and pandrug-resistant bacteria: an international expert proposal for interim standard definitions for acquired resistance. Clin Microbiol Infect. 2012;18(3):268-281. doi: 10.1111/j.1469-0691.2011.03570.x

35. Shokry M, Elhewala A, Megahed A, Fakhr A. Incidence of Vancomycin Resistant Enterococci Colonization in Zagazig University Pediatric ICU. Egy J Med Microbiol. 2018;27(1):17-24.

36. Arias CA, Contreras GA, Murray BE. Management of multidrug-resistant enterococcal infections. Clin Microbiol Infec. 2010;16(6):555-562. doi: 10.1111/j.1469-0691.2010.03214.x

37. Wilcox M, Al-Obeid S, Gales A, et al. Reporting elevated vancomycin minimum inhibitory concentration in methicillin-resistant Staphylococcus aureus: consensus by an International Working Group. Future Microbiol. 2019;14(4):345-352. doi: 10.2217/fmb-2018-0346

38. Gangurde N, Mane M, Phatale S. Prevalence of multidrug resistant Enterococci in a tertiary care hospital in India: A growing threat. Open J Med Microbiol. 2014;4(1):11-15. doi: 10.4236/ ojmm.2014.41002

39. Bhatt P, Patel A, Sahni AK, et al. Emergence of multidrug resistant enterococci at a tertiary care centre. Med J Armed Forces India. 2015;71(2):139-144. doi: 10.1016/j.mjafi.2014.08.007

40. Shridhar S, Dhanashree B. Antibiotic Susceptibility Pattern and Biofilm Formation in Clinical Isolates of Enterococcus spp. Interdiscip Perspect Infect Dis. 2019;2019:1-6. doi: 10.1155/2019/7854968

41. Lee WG, Huh JY, Cho SR, Lim YA. Reduction in glycopeptide resistance in vancomycin-resistant enterococci as a result of vanA cluster rearrangements. Antimicrob Agents Chemother. 2004;48(4):1379-1381. doi: 10.1128/AAC.48.4.1379-1381.2004

42. Strateva T, Atanasova D, Mitov I, Sirakov I, Katrandjieva A. Emergence of VanB phenotype-vanA genotype Enterococcus faecium clinical isolate in Bulgaria. The Brazilian Journal of Infectious Diseases. Braz J Infect Dis. 2014;18(6):693-695. doi: 10.1016/j. bjid.2014.06.005

43. Szakacs T, Kalan L, McConnell M, et al. Outbreak of Vancomycin-Susceptible Enterococcus faecium Containing the Wild-Type vanA Gene. J Clin Microbiol. 2014;52(5):1682-1686. doi: 10.1128/JCM.03563-13

44. Helmi H, Aboulfadl L, El-Din SS, El-Defrawy I. Molecular characterization of antibiotic resistant enterococci. Res J Med Sci. 2008;12(Supp. 1):E273. doi: 10.1016/j. ijid.2008.05.735

45. El-Ghazawy IF, Okasha HAS, Mazloum SM. A study of high-level aminoglycoside resistant enterococci. Afr J Microbiol Res. 2016:10(16):572-577. doi: 10.5897/ AJMR2015.7943

46. Kurtgoz SO, Ozer B, Inci M, Duran N, Yula E. Vancomycin and high-level aminoglycoside resistance in Enterococcus species. Microbiol Res. 2016;7(1):2328. doi: $10.4081 / \mathrm{mr} .2016 .6441$

47. El-Mahdy R, Mostafa A, El-Kannishy G. High level aminoglycoside resistant enterococci in hospitalacquired urinary tract infections in Mansoura, Egypt. Germs. 2018;8(4):186-190. doi: 10.18683/ germs.2018.1145

48. Sienko A, Wieczorek P, Wieczorek A, et al. Occurrence of high-level aminoglycoside resistance (HLAR) among Enterococcus species strains. Prog Health Sci. 2014;4(1):179-187.

49. Sharifi $Y$, Hasani A, Ghotaslou R, et al. Virulence and antimicrobial resistance in enterococci isolated from urinary tract infections. Adv Pharm Bull. 2013;3(1):197201.

50. Das AK, Nandy S, Dudeja M. Prevalence of aac $\left(6^{\prime}\right)$-leaph (2 ")-la gene and drug resistance pattern of Enterococcus isolated in a tertiary care hospital. Int J Community Med Public Health. 2015;2(4):520-525. doi: 10.18203/2394-6040.ijcmph20151041 
51. Behnood A, Farajnia S, Moaddab SR, Ahdi-Khosroshahi R, Katayounzadeh A. Prevalence of aac $\left(6^{\prime}\right)$-le-aph (2 ")-la resistance gene and its linkage to Tn5281 in Enterococcus faecalis and Enterococcus faecium isolates from Tabriz hospitals. Iran J Microbiol. 2013;5(3):203-208.

52. Dahlen G, Blomqvist S, Almsta A, Carlen A. Virulence factors and antibiotic susceptibility in Enterococci isolated from oral mucosal and deep infections. J Oral Microbiol. 2012;4(1):10855-10862. doi: 10.3402/jom. v4i0.10855

53. Vankerckhoven V, Van Autgaerden T, Vael C, et al. Development of a multiplex PCR for the detection of asa1, gelE, cylA, esp, and hyl genes in enterococci and survey for virulence determinants among European hospital isolates of Enterococcus faecium. J Clin Microbiol. 2004;42(10):4473-4479. doi: 10.1128/ JCM.42.10.4473-4479.2004

54. Shahi F, Hamidi H, Khoshnood S, Mehdipour G, Dezfouli A, Sheikh A. Virulence determinants and biofilm formation in clinical isolates of Enterococcus: A crosssectional study. J Acute Dis. 2020;9(1):27-32.

55. Zheng J-X, Bai B, Lin Z-W, et al. Characterization of biofilm formation by Enterococcus faecalis isolates derived from urinary tract infections in China. $J$ Med Microbiol. 2018;67(1):60-67. doi: 10.1099/ jmm.0.000647

56. Tenke P, Kovacs B, Jackel M, Nagy E. The role of biofilm infection in urology. World J Urol. 2006;24(1):13-20. doi: 10.1007/s00345-005-0050-2

57. Hancock LE, Perego M. The Enterococcus faecalis fsr two-component system controls biofilm development through production of gelatinase. $J$ Bacteriol. 2004;186(17):5629-5639. doi: 10.1128/ JB.186.17.5629-5639.2004

58. Soares RO, Fedi AC, Reiter KC, Caierao, J, d'Azevedo PA. Correlation between biofilm formation and gelE, esp, and agg genes in Enterococcus spp. clinical isolates. Virulence. 2014;5:(5):634-637. doi: 10.4161/ viru. 28998

59. Kadhem HS. Evaluation of Virulence Factors and Detection of vanA, vanB and esp Genes from Clinical Isolates of Vancomycin-Resistant Enterococcus faecalis. J Pure Appl Microbiol. 2018;12(2):647-663. doi: 10.22207/JPAM.12.2.23 